\title{
The European Elections 2019 in Greek - Cypriot print Media. The Positions of the Newspapers Alithia and Haravgi in May 2019
}

\author{
Euripides Antoniades \\ Correspondence: Faculty of Communication and Mass Media, Department of Communication \& Internet Studies, Cyprus \\ University of Technology, Limassol, Cyprus.
}

Received: Oct. 13, 2020

doi:10.11114/smc.v8i2.5043
Accepted: Nov. 16, $2020 \quad$ Online Published: Nov. 17, 2020

URL: https://doi.org/10.11114/smc.v8i2.5043

\begin{abstract}
The role of the media during the European election is extremely important as it is the dominant form factor of news and public communication. In this context, both civil society and political actors are the two additional players in the triangle of shaping and influencing communication for social issues. The purpose of this paper is to investigate the agenda and the way in which the news of Greek Cypriot print media was framed. Specifically, this research examines the main topics identified in the printed media during the pre-election period of the European elections in Cyprus in May 2019. Also, this research focuses on how the issues of the news appeared. This research seeks to answer the above questions, thus enriching the research gap found in the existing literature. From a theoretical point of view, this article adopts the theories of the Agenda Setting and Framing, because as interrelated theories they can explain the research theme. In addition, for the purposes of the survey, a mixed methodological approach was applied, with the research adopting quantitative content analysis and framing. Our methodology was based on elements of content quality analysis and aims to analyse the content of the text message, discourse and form and involves five stages: 1 . The procedure of compiling the empirical evidence. 2. The isolation of items (units recorded). 3. The classification of units into categories. 4 . The quantity conversion and measurement of items (codification). 5. Analysis and interpretation of data. The findings showed that the Media Agenda during the pre-election period included a wide range of topics. The topics that had the highest frequency appearance in the media were the economy, society, and environment issues.
\end{abstract}

Keywords: Cyprus, European elections 2019, print media, agenda setting, framing, news

\section{Introduction}

Cyprus is a small country, Member State of the European Union, with a population in the free areas of 840,407 (2011 census). It has made its own way across, it gave battles through adverse circumstances and it is currently the only Member State of the European Union that is still partly occupied by another country, namely Turkey, following the Turkish invasion on the island of 1974. Cyprus joined the European Union on 1 May 2004 and is in harmonisation with the political, economic and cultural acquis communautaire. Cyprus has been a Member State of the European Union for sixteen years now and has received considerable financing from the European funds, therefore achieving social and economic progress and development. On the other hand, there are topics of European political culture, such as citizen engagement in public affairs, which receive little coverage by the Greek Cypriot media (post-elections research 2019). It is a fact that media can form the topics of public debate and transfer issues important to the public. Part of the news agenda settings includes news by the political parties. In that framework, the purpose of this study is to explore how political parties use the press as a mass medium so to inform and influence public opinion. For the conduct of this investigation, quantitative content analysis will be used in conjunction with qualitative analysis. Quantitative analysis of content because it deals with what is said and qualitative analysis to study how something is said. Our effort is to show that the Greek Cypriot press covered the election period (three weeks) for the 2019 European elections.

\section{Stance Towards the EU}

As claimed by Demerzis (1997), stance towards European affairs depends on short-term social-economic fluctuations, as well as on political-cultural factors. According to Eurobarometer surveys, in 2004, 56\% of people believed that Cyprus would benefit from its accession to the EU. Cyprus's accession to the European Union brought significant changes on both the economic and social level. Sixteen years later, the Republic of Cyprus has indeed benefited from EU membership. Back then, most political parties were in favour of the accession, but the situation shifted after the haircut on Cypriot 
depositors as part of the 2013 bailout, when political parties adopted a different attitude towards EU institutions (Eurobarometer survey 2013). In 2013, an approach was used to address the economic crisis for the first time ever: a bank deposit levy (haircut) was imposed and banks closed for several days - this was unique to Cyprus and unprecedented. Moreover, Cyprus has witnessed the European Union's weakness in expressing its practical support for the violations of the Cypriot Exclusive Economic Zone by Turkey. But it is important to remember that Cyprus's accession to the European Union has contributed to the political, economic and military expansion of the EU to the Middle East.

\section{Low Turnout in the European Elections}

The phenomenon of increasingly low turnout in elections is generally observed in Europe. In Cyprus, the lowest turnout was recorded in the European Elections of 2014, with 56\% of voters not casting their ballot. In the 2019 European Elections, this percentage was roughly the same, i.e. 55\%. The low turnout can be attributed to the general indifference regarding EU affairs shown by Cypriot citizens, but it is also a sign of the level of political discourse and political culture, locally. From 2013 onwards, the Cypriot electorate was affected by the frustration and disappointment felt by society as a result of the economic collapse brought by Eurogroup, an informal body of the EU. As a consequence, masses of citizens did not turn up to vote. Therefore, it is up to the European Union to convince citizens that voting is worth the effort.

\section{Discussion}

European elections are held in EU Member States to elect new members of the European Parliament. The European Parliament is the only body of the EU which is elected directly by the people, and it is important to note which criteria push Cypriot voters to cast their ballots. One criterion for Cypriot voters is the economy and development (50\%) (Postelections Research 2019). A second factor is the curb on youth unemployment (47\%). A third factor - which is as important as the first two - is the promotion of human rights and democracy (37\%). The media have a fundamental role in shaping these trends in elections, since they determine the framing and set the agenda of public discourse, therefore affecting public perceptions regarding the EU. After researching news items regarding EU affairs, we analysed news coverage in the printed press during the pre-election campaign for the 2019 European Elections. We argue that news framing includes priority setting by reporters and editors, and the angles or lenses through which journalists choose to tell a story (Wallington, 2010). So, in the study, we are going to explore the priority the press gives to the political parties and how the news about the European elections is presented.

\section{The Print Media}

Newspapers and magazines are part of print media. Moreover, the print media gave readers the chance not only to read the news but also to broaden the horizon of their knowledge. At the same time, the power of print media depends on their readers' trust and the way they present the news. Print media are key to the setting of agendas and focusing public interest on particular subjects. It is important to mention that some readers' they develop a trust link with print media, and they choose to learn the news from that source. Print media is more credible than digital media because in Internet do not always have regulation and editorial standards. In addition to these websites, sometimes publish fake news to increase their readers, traffic, online sharing and clicks. So, print media are more objective because they record news with time distance and they offer adequate analysis, pluralism, commentary, interview's and documentation (Clausen, 2003).

As argued by Papathanasopoulos (2019) newspapers, historically, were forced to divide their business with the radio from the 30s onwards and with the television from the 50s onwards. During the course of time, newspapers survived only due to their constant effort to adjust to technological innovations and to the evolving trends and needs of the reading public. In addition, newspapers have some advantages that other media do not possess. First of all, their longevity. Secondly, they produce content on a professional basis, which means that they know how to be consistent and in line with what they produce. They have names and surnames, as opposed to the anonymity which dominates the internet. Thirdly, they are more recognisable to the public compared to their digital competitors. Forthly, they generally offer a full service to their readers at a low or affordable cost.

The print media chosen were Alithia and Haravgi Greek Cypriot newspapers.

Alithia (Sofocleous, 2011) newspaper was founded in 1952 by the late Antonis Farmakides as a weekly newspaper. Antonis Farmakides is considered one of the pioneers of Cypriot journalism. Weekly Alithia, following its Monday issue on 15 July 1974, was forced to suspend its circulation for a few weeks due to the events that took place as a result of the military coup and the subsequent Turkish invasion. It re-circulated on 5 August 1974 with a detailed report on the tragedy that hit Cyprus and an optimistic message.

Today, Alithia ${ }^{1}$ has completed 68 years of presence as a daily newspaper. Through the years that are intertwined with the

${ }^{1}$ Alithia, May 1, 2020. Available online: http://alithia.com.cy/digital/arxeiopdf/2020-05-01.pdf (accessed on 27 September 2020). 
evolving democratic maturity of the Cypriot people, Alithia remains true to its principles and continues to give its own struggle so that Cyprus can see better days. In 1980, its current editor Frixos Koulermos took over and converted it into a daily, morning newspaper. Alithia became daily so that its voice could be heard during times that did not favour polyphony.

Haravgi (Haravgi is the "official expressive organ" of the political party AKEL) (Sofocleous, 2011) newspaper celebrates 64 years of life and is rightfully proud because, over the years, it stood in support of workers' rights, democracy and the concept for a common, free country. Through the circumstances of the brutal oppression imposed by the British colonial regime, Haravgi picked up the torch from the New Democrat, sending a strong message, from even its first issue that the voice of the left cannot be silenced. Through all the years of its presence in the political and social life of the island, Haravgi did not just record Cyprus reality, but also associated its presence with the modern history of Cyprus. From the first day of its establishment, it promoted and defended the correctness of the position for mass political struggle of the Cypriot people for independence from the British rule. Haravgi worked against all the plans that aimed at selling off Cyprus and its people, and resisted the imperialistic plans aiming at dividing the island. It raised its voice against the nationalist-chauvinist opinions and it stood shoulder by shoulder with AKEL (Progressive Party of Working People) in the quest for re-approach of the two Cypriot communities and peaceful living. It fought against inequality, discriminations, xenophobia, racism, fanaticism, bigotry, quelling and depoliticization. We cannot forget who opened the roads for this newspaper. We cannot forget intellectual titans of progressive thought that wrote columns for this newspaper, such as Tefkros Antias, Theodosis Pierides, Iakovos Rossides and many others. With the power given to it by its readers, Haravgi promises to continue with the same amount of responsibility and the same passion following Pieridis's lyric "this thirst will not quench, this flame will not burn out, even after a thousand years, we will not die slaves".

\section{Methodology}

In order to meet the research objectives and in order to carry out a detailed and multi-dimensional analysis, a mixed methodological approach has been implemented, namely a qualitative and quantitative method. This method has been selected as the most appropriate to describe the trend in covering European issues in the Cypriot daily agenda. The research involves recording the relevant news items found in two daily newspapers of island-wide circulation and identifying the main headlines and other news contributing to the extent of coverage of the European Parliament election.

The research covers the last three weeks of the campaign (06/06/19-26/06/19). Each publication in a newspaper (headline, small news item, opinion piece, etc.) referring to the European elections was a unit of analysis. The research material was collected from two newspapers of island-wide circulation. The units of analysis in the newspapers were categorised based on number and size, type (editorial, reportage, opinion or interview), their position in the newspaper (political column, international column, economic column, other), the thematic content and framing.

In the first stage, we identify the empirical material, i.e. the news item or items that are relevant to the study. In the second stage, we isolate the items and decide where they belong. In the third stage, we classify them, i.e. we divide them into categories. In the fourth stage, we convert the quantitative material into a form that allows computerised processing that will enable us to compare it and describe it (Constantinidou, 1998). In the final stage, we present the data, their analysis and interpretation. At this final stage, the conclusions are extracted.

\section{Coverage}

In this part, we present the findings that occurred through the data analysis of the two newspapers we study. As a first step, we present the thematic categories of the news items identified in the media during the period of data collection and the frequency in which they appear. Afterwards, we provide the findings of the research regarding the agenda of each newspaper separately, the sources of information on European Union issues and the selection criteria of European news items. 


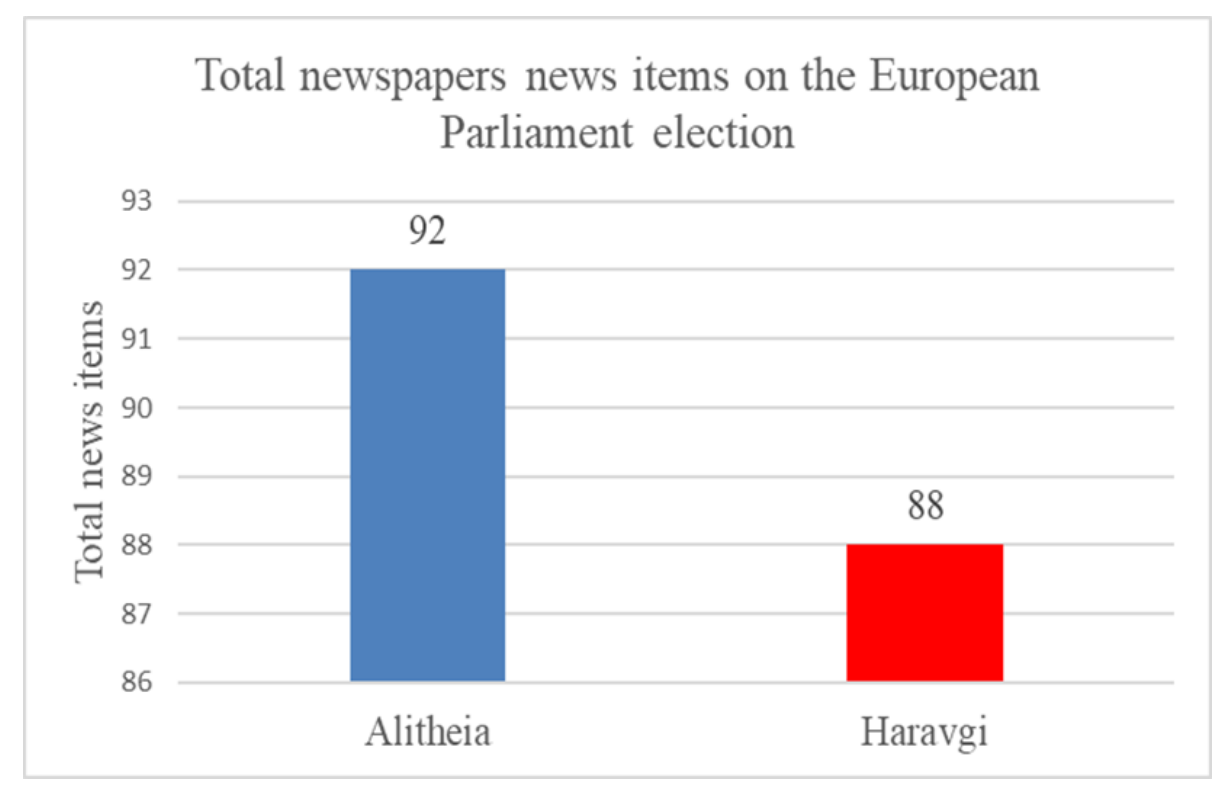

Figure 1. The coverage of the European elections by Alithia and Haravgi

With the exception of $O$ Phileleftheros, the two newspapers represent approximately $60 \%$ of readers on island and the largest part of the political spectrum. Coverage distribution is balanced and ranges between $49 \%$ and $51 \%$ of the total published items (See Graph 1).

Table 1. Total news items on the European Parliament election per week in the press:

\begin{tabular}{lcccc}
\hline & $\begin{array}{c}06 / 05 / 2019- \\
12 / 05 / 2019\end{array}$ & $\begin{array}{c}13 / 05 / 2019- \\
19 / 05 / 2019\end{array}$ & $\begin{array}{c}20 / 05 / 2019- \\
26 / 05 / 2019\end{array}$ & $\begin{array}{c}\text { News Total } \\
\text { Number }\end{array}$ \\
\hline Print Media & & & & \\
\hline Alithia & 26 & 32 & 34 & 92 \\
Haravgi & 28 & 23 & 37 & 88 \\
\hline Total & 54 & 55 & 71 & 180 \\
\hline
\end{tabular}

Table 1 shows the total number of news items generated per week during the period between 6/05/2019 and 26/05/2019 in Alithia and Haravgi. Here, we observe that from week to week and as the European elections approach, the European news is increasing.

\section{Agenda Settings}

Lippmann (1988:322) states that "the press is like a roaming spotlight, bouncing from topic to topic, story to story, illuminating things", supporting at the same time that the mass media construct the views of individuals on social affairs.

In view of this, the agenda setting theory focuses on the study and promotion of the total procedures that transform social events into public issues (Garraud, 2010, cited in Kountouri,2015). In other words, agenda setting is a fluid procedure which comes down to the compilation of a list of issues which must be regulated by the actors involved.

In addition, starting with the general definition of agenda, Dearing and Rogers (2005) argue that there are three main components of the agenda-setting process: media agenda, public agenda and policy agenda. In essence, these three components are the main "ground" where all the different issues claim space. 
Table 2. Areas covered by European news - Alithia

\begin{tabular}{ccccc}
\hline Agenda & Week 1 & Week 2 & Week 3 & Total \\
\hline Economy & 8 & 4 & 3 & 15 \\
Politics & 12 & 13 & 11 & 36 \\
Society & 6 & 15 & 19 & 40 \\
\hline Total & 26 & 32 & 33 & 91 \\
\hline
\end{tabular}

As observed in Table 2 above, the categories were split in three thematic units: a) economy, b) politics, c) society. In most cases, a European news item dealt with the actions of Greek Cypriot political parties and this was happening during the last three weeks of the pre-election campaign. In more detail, Table 2 shows the thematic categories of news that emerged during the period 6/05/2019 - 26/05/2019 in Alithia newspaper. The main topics were: society with 40 items (44\%), followed by politics with 36 items (39\%) and economy with 15 items (17\%). The titles below are indicative of the agenda of the newspaper:

\section{Society:}

- "Registration of children on the General Health System (GESY) has started" (Alithia, 7 May 2019)

- “Migrants: Europe's open wound, a pain for Cyprus" (Alithia, 11 May 2019)

Politics:

- $\quad$ “Cyprus achieved the global condemnation for the Turkish provocations - 'Fatih' surrounded by international vessels (Alithia, 7 May 2019)

- "Chavousoglou: Turkey now condemns the European Union” (Alithia, 19 May 2019)

Economy:

- “European Economy: Enhanced development from 2020” (Alithia, 8 May 2019)

- "Energy Minister: Eight drillings within the next 24 months in the Exclusive Economic Zone of Cyprus" (Alithia, 22 May 2019)

Table 3. Areas covered by European news - Haravgi

\begin{tabular}{ccccc}
\hline Agenda & Week 1 & Week 2 & Week 3 & Total \\
\hline Economy & 5 & 5 & 3 & 13 \\
Politics & 12 & 10 & 14 & 36 \\
Society & 8 & 8 & 17 & 33 \\
\hline Environment & 3 & -- & 3 & 6 \\
\hline Total & 28 & 23 & 37 & 88 \\
\hline
\end{tabular}

Table 3 shows the agenda of Haravgi newspaper. The newspaper covers political European News. As can be observed, in Table 3, the topics which appeared the most often were: politics with 36 news items (41\%), society with 33 news items (37\%), economy with 13 news items (15\%) and environment with 6 news items (7\%).

More particularly, Haravgi newspaper published the following categories of news items:

Society

- "Implementation of the General Health System despite the problems" (Haravgi, 17 May 2019)

- "Poll: Heading Towards the European election" (Haravgi, 18 May 2019)

Politcs

- “Turkey provocatively insists on the Exclusive Economic Zone - it questions the agreements of Cyprus with the neighbouring countries" (Haravgi, 7 May 2019)

- “AKEL General Secretary: We must become the change - AKEL's vision and proposals for another Cyprus, another Europe" (Haravgi, 18 May 2019)

Economics 
- $\quad$ "Recession in the labour market and a downturn for development - Alert from the Commission on the report for Spring forecasts" (Haravgi, 8 May 2019)

- "European Bank for Reconstruction and Development and Cyprus" (Haravgi, 12 May 2019)

Environment

- "Human activity and nuisance threats the Mediterranean seal" (Haravgi, 20 May 2019)

- "Cyprus is a leader in... municipal waste generation - A valuable resource only if EU legislation is implemented” (Haravgi, 15 May 2019)

It is widely accepted that Cypriot newspapers are political, as they are in Greece (Papathanasopoulos, 1997). Moreover, as observed by Papathanasopoulos (2002:177), another reason why politics are the first choice in the framework of the European agenda is the tradition in journalism of South Europe - and especially the Mediterranean - whereby reporters comment on news through a clear political perspective.

At this point, we need to note that there is a trend in Cyprus for the mass media to be controlled by private interests, which seek to achieve their political objectives through their political connections. The Cypriot paradigm is typical because both newspapers are partisan and belong to strong media groups that use their power to lobby and influence politicians. It is important to stress that the number of news items is low and this is due to the technological advantage and directness of the internet. Moreover, the quality of European news may be considered one additional reason why European news have restricted coverage in the press. Gavin (2001) claims that European news are not powerful and interesting from a news reporting point of view.

Table 4. Areas covered by European news - Haravgi

\begin{tabular}{ccccc}
\hline Article written by & Week 1 & Week 2 & Week 3 & Total \\
\hline News reporter & 44 & 54 & 56 & 154 \\
International agency & 11 & 9 & 13 & 33 \\
$\begin{array}{c}\text { International) news } \\
\text { networks }\end{array}$ & - & - & - & - \\
Other source & - & - & - & - \\
\hline Total & 55 & 63 & 69 & 187
\end{tabular}

Table 4 shows the main sources of information regarding the coverage of European news. The main source of information for newspapers is reporters. Both newspapers have their reporters and, therefore, 154 news items $(82 \%)$ were written by reporters, followed by 33 news items (18\%) originating from International Agencies.

\section{Framing}

As was the case in most of the 27 EU member states, the campaign of the 2019 European Parliament election was characterised by mildness and apathy. This is not normally the setup during election campaigns in Cyprus, but this time there were two specific factors that contributed to a laid back atmosphere: first of all, the election coincided with the shocking news about a serial killer who murdered seven women and, secondly, the campaigns focused on the election or non-election of Turkish Cypriot candidate Dr Niazi Kizilyurek. Therefore, a mild tone was adopted during the election campaigns and the partisan mechanism and patriotism had low levels of alertness. A typical example is the article published by Alithia titled "political leaders attempted yesterday, at the last minute, to mobilise even the last potential voter, therefore aiming to achieve the best possible outcome for Sunday evening" (Alithia, 25 May 2019). Moreover, the President of the Republic of Cyprus Mr. Nicos Anastasiades states that "on Sunday we do not have presidential elections" (Alithia, 25 May 2019). In addition, we also observe that the pre-election atmosphere intensified only over the last week of the campaign in view of Turkey's violations in the Exclusive Economic Zone of the Republic of Cyprus. In conclusion, the mass media covered the European Parliament election campaign with a non-conflict tone. In this study, we examined the framing of news items in two different types of news reports: those that focused on European matters and those that focused on partisan strategy. As shown in graphs 2 and 3, the press adopted a non-conflict framing for both types of news reports. 


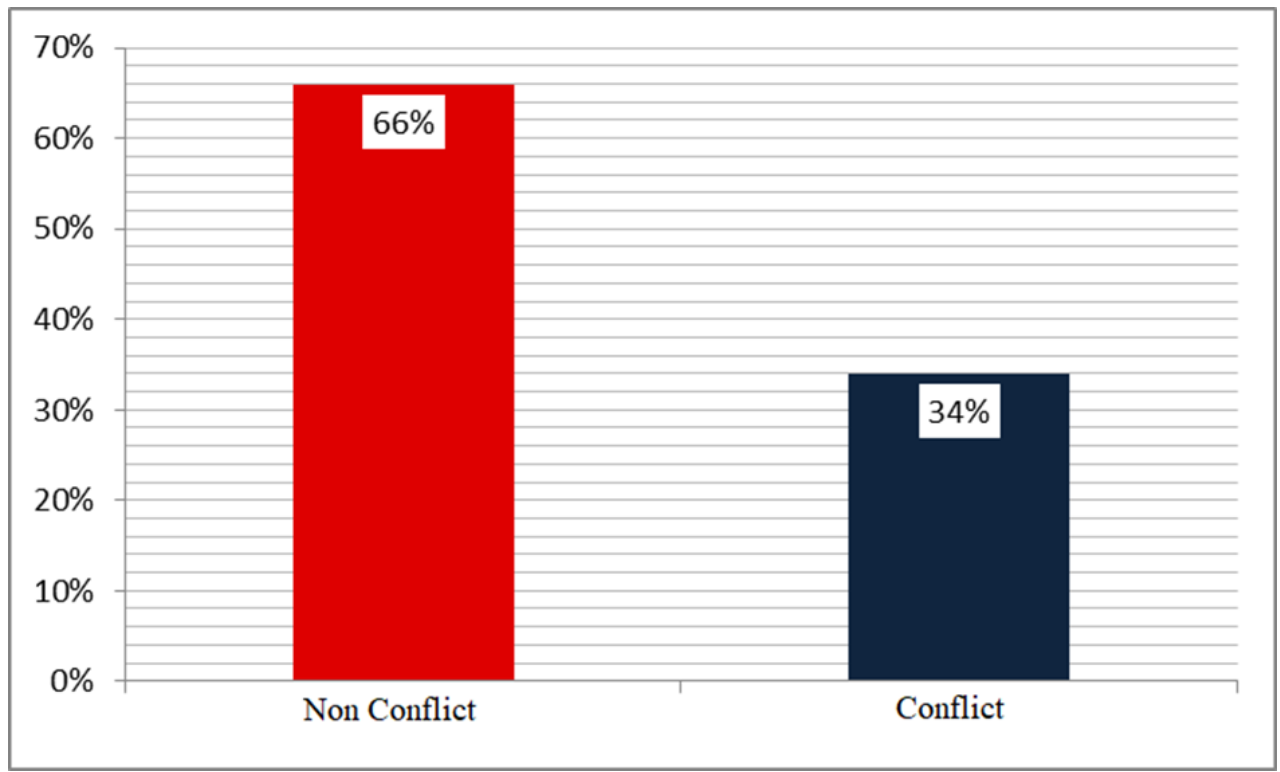

Figure 2. The framing of news items in Alithia newspaper

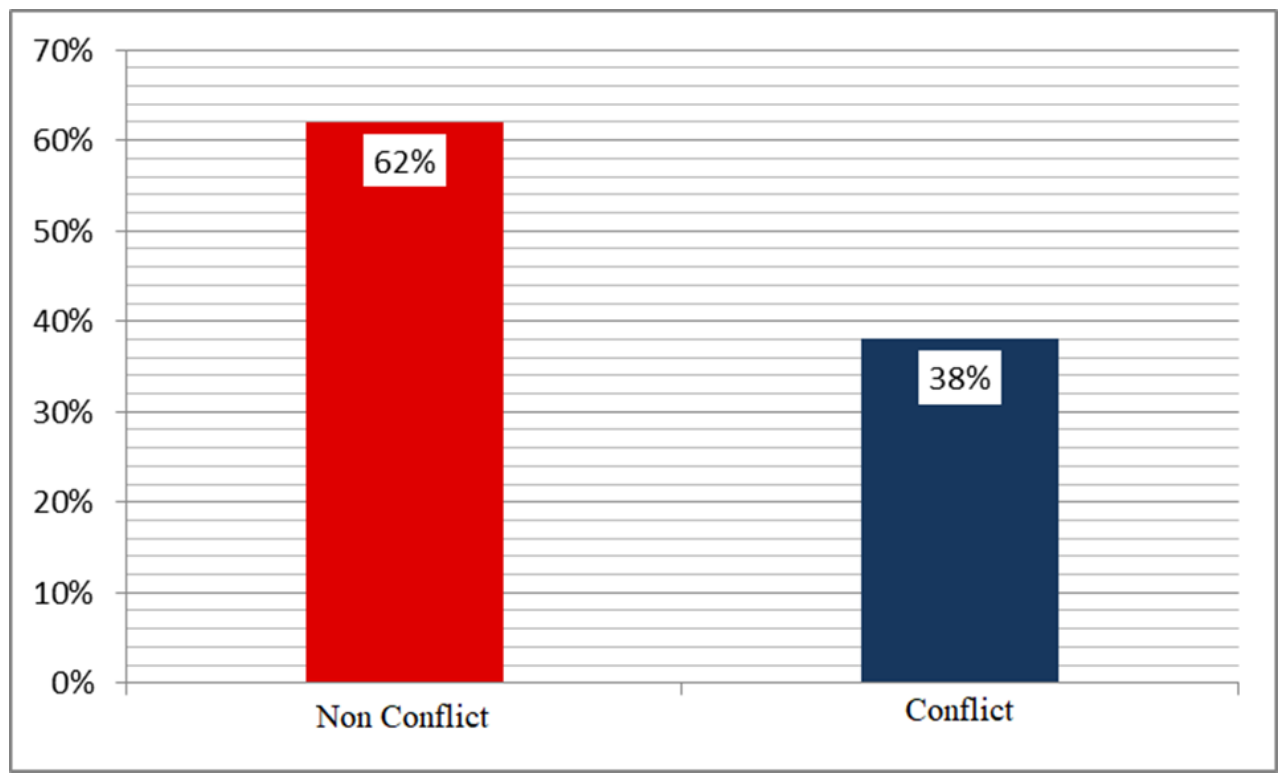

Figure 3. The framing of news items in Haravgi newspaper

\section{Conclusions}

In conclusion, the main findings of this research are summed up as follows:

a) most news items regarding the European parliament election in Cyprus referred mainly to Cypriot political parties and interior topics (covering primarily the local pre-election activity) rather than European affairs.

b) reporters were the main sources of several European news items in the newspapers

most news reports were framed in a non-conflict way.

The way in which the two newspapers covered the European elections did not highlight the gap between Europe and its citizens, nor did the press contribute to building the European public sphere. For the Cypriot public, the EU remains an important, yet distant and difficult-to-grasp political entity. The more they know about the EU, the more they will be directed towards unification. And this creates a challenge for national mass media. On the other hand, this comes as a surprise since Cyprus, due to its size, geographical position and solution search problems, has heavily invested to tis EU membership. Our findings confirm that any country, society regardless her size, pays attention to domestic issues and 
concerns. The international dimension comes a second priority. The news media simply reflect this relationship and newspapers in particular refer primarily to their home markets and citizens' concerns.

So, we can conclude that press writes what readers want to read what they want to hear (Jacobsen, 2013). If we consider the fact that according to Eurobarometer 2019 Cypriot main concern is youth unemployment(72\%), ecnomy and growth(72\%), security and defence $(43 \%)$, we can explain why the press choose to focus on economy, politics and society and not to European elections. In the future, we plan to expand the research reported in this paper. One possible direction would be to examine the research topic in two phases before and after the elections. This would reveal the agenda setting differences between the topics and the context the press appears between the two periods. Also, the link between agendasetting and news frameworks with candidates for the European elections could be explored. Another direction would also be to investigate the agenda setting about the European elections in the Turkish Cypriot press.

\section{References}

Clausen, L. (2003). Global news production. Copenhagen Business School.

Constantinidou, C. (1997). Representing the Allocation of Labour according to Sex in the Daily Athens Mass Press. [Doctoral dissertation, Panteion University].

Dearing, J. W., \& Rogers, E. M. (2005). Agenda-setting (P. Tsiligiannis, Trans.). Papazisis.

Demetzis, N. (1997). Greece. In R. Eatwell (Eds.), European political cultures: conflict or convergence? (pp. 107-121). Routledge.

Eurobarometer (2004). Public Opinion Research.

Eurobarometer (2013). Public Opinion Research.

Eurobarometer (2019). After Election Research.

Gavin, N. T. (2001). British journalists in the spotlight: Europe and media research. Journalism: Theory, Practice \& Criticism, 2, 299-314. https://doi.org/10.1177/146488490100200301

Jacobsen, A. P. (2013). Lights, camera, vote: an agenda-setting analysis of celebrity endorsements and news correlation during the 2012 presidential election (Master's thesis). Liberty University, Lynchburg, Virginia, USA. Retrieved from https://core.ac.uk/download/pdf/58825346.pdf

Kevin, D. (2003). Europe in the media: a comparison of reporting, representation and rhetoric in national media systems in Europe; L. Erlbaum Associates.

Leroy, P., \& Siune, K. (1994). The Role of Television in European Elections: The Cases of Belgium and Denmark. European Journal of Communication, 9, 47-69. https://doi.org/10.1177/0267323194009001003

Lippmann, W. (1988). Public opinion (G. Karagiannis, Trans.). Kalvos.

Papathanassopoulos, S. (1997). The Politics and the Effects of the Deregulation of Greek Television. European Journal of Communication, 12, 351-368. https://doi.org/10.1177/0267323197012003003

Papathanassopoulos, S. (2002). European television in the digital age. Polity.

Semetko, H. A., \& Valkenburg, P. M. V. (2000). Framing European politics: A Content Analysis of Press and Television News. Journal of Communication, 50(2), 93-109. https://doi.org/10.1111/j.1460-2466.2000.tb02843.x

Sofocleous, A. K. (2011). The history of Cyprus press, Nicoreon.

Wallington, S. F., Blake, K., Taylor-Clark, K., \& Viswanath, K. (2010). Antecedents to agenda setting and framing in health news: An examination of priority, angle, source, and resource usage from a national survey of U.S. health reporters and editors. Journal of Health Communication, 15(1), 76-94. https://doi.org/10.1080/10810730903460559

\section{Copyrights}

Copyright for this article is retained by the author(s), with first publication rights granted to the journal.

This is an open-access article distributed under the terms and conditions of the Creative Commons Attribution license which permits unrestricted use, distribution, and reproduction in any medium, provided the original work is properly cited. 